\title{
Gypenoside XLIX isolated from Gynostemma pentaphyllum inhibits nuclear factor-kappaB activation via a PPAR-alpha-dependent pathway
}

\author{
Tom Hsun-Wei Huang, Yuhao Li, Valentina Razmovski-Naumovski, Van Hoan Tran, \\ George Qian Li, Colin C. Duke \& Basil D. Roufogalis* \\ Pharmaceutical Chemistry Discipline and Herbal Medicines Research and Education Centre, Faculty of \\ Pharmacy, University of Sydney, A15, S322, Sydney, NSW, 2006, Australia
}

Received 21 June 2005; accepted 26 January 2006

(C) 2006 National Science Council, Taipei

Key words: Gynostemma pentaphyllum, gypenoside, nuclear factor-kappaB, peroxisome proliferatoractivated receptor-alpha

\begin{abstract}
Summary
Nuclear factor (NF)- $\kappa \mathrm{B}$ is important in the generation of inflammation. Besides regulating lipid metabolism, peroxisome proliferator-activated receptor (PPAR)- $\alpha$ activators also reduce NF- $\kappa$ B activation to terminate activation of inflammatory pathways. Gynostemma pentaphyllum (GP) has been used to treat various inflammatory diseases and hyperlipidemia. Here, we demonstrate that GP extract and one of its main components, Gypenoside XLIX (Gyp-XLIX) inhibited LPS-induced NF- $\kappa$ B activation in murine macrophages. Furthermore, Gyp-XLIX restored the LPS- and TNF- $\alpha$-induced decrease in cytosolic I- $\kappa \mathrm{B} \alpha$ protein expression and inhibited the translocation of NF- $\kappa \mathrm{B}(\mathrm{p} 65)$ to the nucleus in THP-1 monocyte and HUVEC cells. The inhibition of LPS- and TNF- $\alpha$-induced NF- $\kappa$ B luciferase activity in macrophages was abolished by MK-886, a selective PPAR- $\alpha$ antagonist. GP extract and Gyp-XLIX (EC 50 : $10.1 \mu \mathrm{M})$ enhanced PPAR- $\alpha$ luciferase activity in HEK293 cells transfected with the tK-PPREx3-Luc reporter plasmid and expression vectors for PPAR- $\alpha$. Additionally, Gyp-XLIX specifically enhanced PPAR- $\alpha$ mRNA and protein expression in THP-1-derived macrophage cells. The selectivity of Gyp-XLIX for PPAR- $\alpha$ was demonstrated by the activation of only PPAR- $\alpha$ in HEK293 cells transfected with expression vectors for PPAR- $\alpha$, PPAR- $\beta / \delta$ or PPAR- $\gamma 1$ plasmids and in THP-1-derived macrophage naturally expressing all three PPAR isoforms. The present study demonstrates that Gyp-XLIX, a naturally occurring gynosaponin, inhibits NF- $\kappa$ B activation via a PPAR- $\alpha$-dependent pathway.
\end{abstract}

Abbreviations: BSA - bovine serum albumin; EDTA - ethylenediaminetetraacetic acid; GP - Gynostemma pentaphyllum; Gyp-XLIX - gypenoside XLIX; HEK293 - human embryonic kidney 293; HUVEC - human umbilical vein endothelial cells; iNOS - inducible nitric oxide synthase; I- $\kappa \mathrm{B}$ - inhibitor- $\kappa \mathrm{B}$; LPS lipopolysaccharide; NF- $\kappa \mathrm{B}$ - nuclear factor-kappaB; NO - nitric oxide; PBS - phosphate-buffered saline; PDTC - pyrrolidine dithiocarbamate; PPAR - peroxisome proliferator-activated receptor; RT-PCR - reverse transcription polymerase chain reaction; SDS - sodium dodecyl sulfate; TNF- $\alpha$ - tumor necrosis factor- $\alpha$

\section{Introduction}

Nuclear factor kappa $\mathrm{B}(\mathrm{NF}-\kappa \mathrm{B})$ is a protein transcription factor required for maximal tran-

\footnotetext{
*To whom correspondence should be addressed. Fax: +61-2-
} 9351-4447, E-mail: basilr@pharm.usyd.edu.au scription of many proinflammatory molecules thought to be important in the generation of inflammation, including certain adhesion molecules (intercellular adhesion molecule 1), critical enzymes (inducible nitric oxide synthase, cyclooxygenase-2), and a number of cytokines (interleukin-1 $\beta$, tumor necrosis factor- $\alpha$, IL-6) and 
chemokines (IL-8) [1-3]. Since these molecules are regulated at the level of transcription and are involved in the inflammatory cascade, modulation of NF- $\kappa \mathrm{B}$ is a critical intracellular pathway in the inflammatory cascade. NF- $\kappa$ B is sequestered in the cytoplasm by the inhibitor-kappaB (I- $\kappa$ B) family of proteins. NF $-\kappa \mathrm{B}$ exists in several dimeric forms, but the p50/p65 heterodimer is predominant. Activation of NF- $\kappa \mathrm{B}$ by a range of physical, chemical and biological stimuli leads to phosphorylation and proteasome dependent degradation of $\mathrm{I}-\kappa \mathrm{B}$, leading to the release of free NF- $\kappa \mathrm{B}$. The freed NF- $\kappa \mathrm{B}$ then binds to its target sites $(\kappa \mathrm{B}$ sites in the DNA), to initiate transcription. This transcription is known to be involved in a number of diseases including cancer, AIDS and inflammatory disorders (see review in [4]), such as lung disease [5] and atherosclerosis [6].

Gynostemma pentaphyllum (GP) Makino (Cucurbitaceae) is a perennial creeping herb grown prevalently throughout China, India, Japan, Korea and Sri Lanka [7], and traditionally prescribed in China as an expectorant for relieving cough and chronic bronchitis and for its diuretic, antipyretic and anti-inflammatory properties [8-10]. GP has been shown to inhibit and reverse the carcinomatous conversions of leukoplasia of golden hamster cheek pouches, indicating its positive anticarcinogenic effect [11]. Gypenosides (dammarane-type glycosides) derived from GP have been demonstrated to suppress LPS-induced nitric oxide (NO) production and inhibit LPS-induced inducible NO synthase (iNOS) enzymatic activity by attenuating $\mathrm{NF}-\kappa \mathrm{B}$ activation [12], and to prevent progression of atherosclerosis [13]. It appears that modulation of the NF- $\kappa$ B pathway plays an important role in the anti-inflammatory effects of GP. However, the active components and molecular mechanism for suppressing NF- $\kappa \mathrm{B}$ activation are still unknown. On the other hand, GP has been recently shown to clinically reduce serum total cholesterol, triglyceride and low density lipoprotein levels, and increase high density lipoprotein [14, 15]. Its mechanism for lipid-lowering is also unclear.

We have recently isolated gypenoside XLIX (GypXLIX, a dammarane-type glycoside, Figure 1b), as one of the main components of GP. The aim of the present study is to clarify the underlying molecular mechanism of GP and Gyp-XLIX for inhibiting NF- $\kappa$ B activation, as well as for lowering lipids.

\section{Materials and methods}

Anti-actin primary antibody, bezafibrate, boric acid, bovine serum albumin (BSA), ciglitazone, ethylenediaminetetraacetic acid (EDTA), lipopolysaccharide (LPS) from Salmonella minnesota, phosphate-buffered saline (PBS), pyrrolidine dithiocarbamate (PDTC), sodium dodecyl sulfate (SDS), Tris-base, tumor necrosis factor (TNF)- $\alpha$, deuterated $\left(\mathrm{d}_{5}\right)$-pyridine $\left(\mathrm{C}_{5} \mathrm{D}_{5} \mathrm{~N}\right) 99.5$ atom $\%$ and filter agent Celite 521 were obtained from SigmaAldrich (Australia). MK-886 was purchased from Biomol (USA). Wy-14643 was purchased from Cayman Chemical (USA). All media and solutions used for tissue culture were obtained from Invitrogen (Australia). Chemicals used in phytochemical procedures were of analytical grade.

\section{Source of GP extract and isolation and identification of Gyp-XLIX}

GP extract containing $>99 \%$ gypenosides was provided by Ankang Pharmaceutical Institute of the Beijing University, People's Republic of China. The extract was repeatedly fractionated using normal phase silica gel short column vacuum chromatography [16]. A stepwise gradient of increasing polarity of the mobile phase system consisting of chloroform:ethyl acetate:methanol was used to elute the sample. The fraction containing Gyp-XLIX was further purified using preparative HPLC eluted with an isocratic condition of $33 \%$ acetonitrile in water and detected at $206 \mathrm{~nm}$. Finally the title compound was identified and characterized by LC/MS, GC/MS and NMR methods. Its spectroscopic data (data not shown) were shown to be identical to that reported in literature [17].

\section{Cell culture}

The human embryonic kidney 293 (HEK293) cell line was obtained from the American Type Culture Collection. The human hepatocellular carcinoma 
cell line (HepG2) was as a kind gift of Dr. Javed Akhter (University of New South Wales, Australia). The human umbilical vein endothelial cells (HUVEC) line was as a kind gift of Dr. Pat Pisansarakit (Heart Research Institute, Australia). The THP-1 human monocytic cell line was as a kind gift of Dr. Asne Bauskin (St. Vincents Hospital, Australia). The HEK293 cells were grown in DMEM/F12 and HepG2 cells were cultured in DMEM. The THP-1 monocytes and macrophages were grown in RPMI 1640 in the presence of $50 \mu \mathrm{M}$ $\beta$-mercaptoethanol. All media contained L-glutamine supplemented with penicillin $(100 \mathrm{U} / \mathrm{ml}) /$ streptomycin $(100 \mu \mathrm{g} / \mathrm{ml})$, and $10 \%(\mathrm{v} / \mathrm{v})$ heatinactivated fetal bovine serum (FBS) in a humidified atmosphere of $5 \% \mathrm{CO}_{2}$ and $95 \% \mathrm{O}_{2}$ at $37{ }^{\circ} \mathrm{C}$. To induce monocyte differentiation into macrophage, the THP-1 monocytes were treated with PMA (400 ng/ml) for $72 \mathrm{~h}$, before Wy-14643, Gyp-XLIX or vehicle $(0.1 \%$ DMSO) were added, and incubated for a further $48 \mathrm{~h}$ in culture medium for the macrophage treatment experiments [18]. The HUVEC cells were grown in M199 medium (Invitrogen Australia) supplemented with 20\% FBS, $50 \mu \mathrm{g} / \mathrm{ml}$ endothelial cell growth supplement (Sigma, Australia), $25 \mathrm{mM}$ Hepes buffer, $2 \mathrm{mM}$ L-glutamine, $100 \mathrm{U} / \mathrm{ml}$ penicillin, and $100 \mathrm{U} / \mathrm{ml}$ streptomycin. The HUVEC cell cultures were used within 3 weeks, between the second and fifth passage. Cytotoxicity of compounds used in the experiments was assessed by cell viability assays and in all conditions showed little or no effect on cell viability ( $>90 \%$ viability remained) (data not shown).

\section{Transfection and luciferase assay}

To determine peroxisome proliferator-activated receptor (PPAR) luciferase activity, the HEK293 cells were transfected as previously described [19, 20]. The plasmids used for transfection were tKPPREx3-Luc plasmid (a kind gift from Dr Teruo

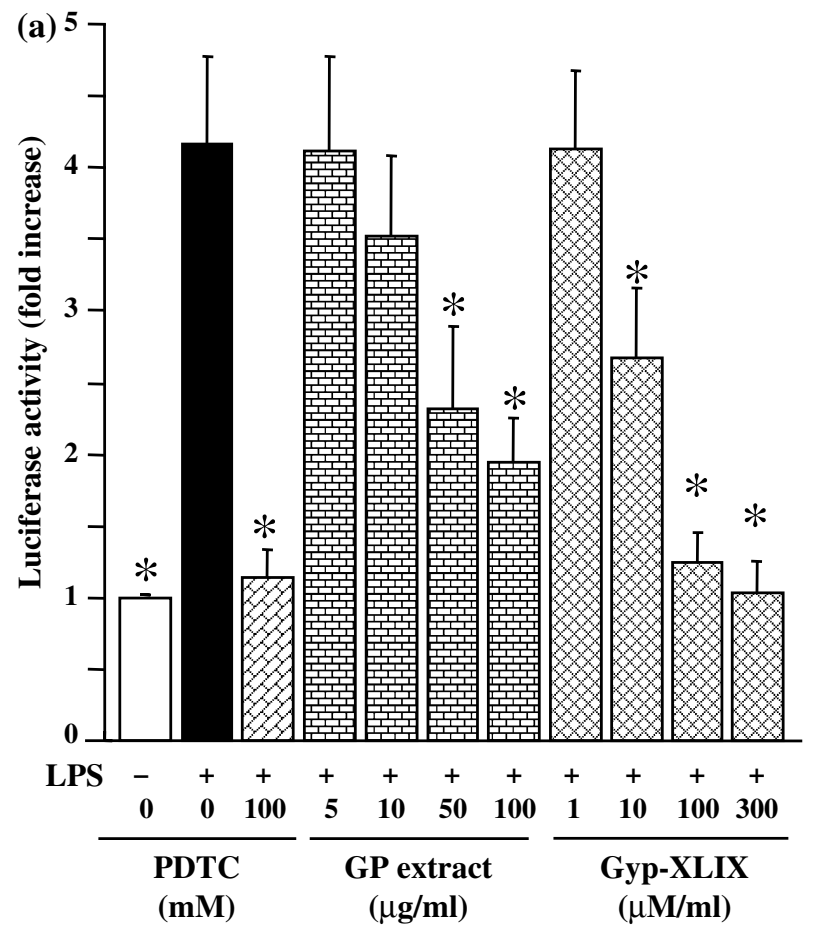

(b)

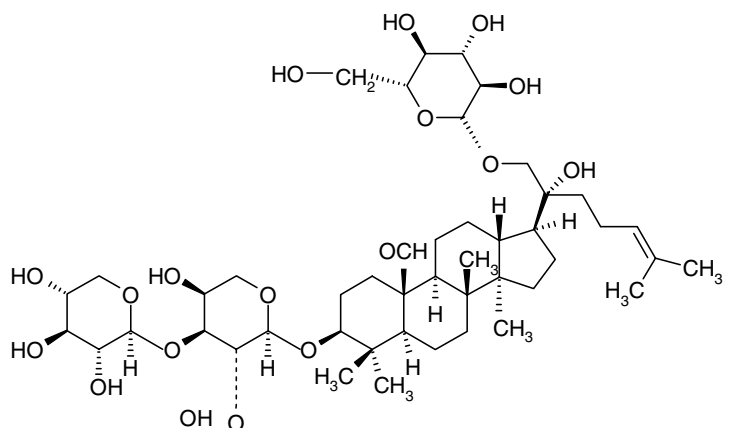

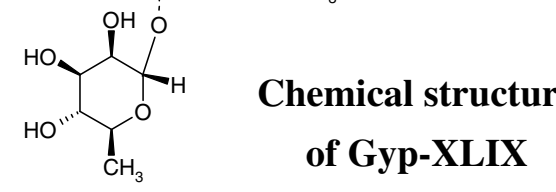

$(M W=1047)$

Figure 1. (a) Effects of the extract from Gynostemma pentaphyllum (GP) and one of its main components Gypenoside XLIX (GypXLIX) on lipopolysacharide (LPS, $1 \mu \mathrm{g} / \mathrm{ml}$ )-induced nuclear factor (NF) $-\kappa \mathrm{B}$ activation in RAW264.7 macrophages transfected with $\mathrm{NF}-\kappa \mathrm{B}$ luciferase reporter gene. The results were expressed as relative luciferase activity (fold difference compared to negative control). Pyrolidine dithiocarbamate (PDTC) was used as a positive control. Levels in vehicle (without LPS) were arbitrarily assigned a value of 1.0. All values are means $\pm \operatorname{SEM}\left(n=3\right.$ each in duplicate) vs. control (PDTC with LPS), ${ }^{*} p<0.05$. Veh: vehicle. (b) Structure of Gyp-XLIX (Molecular weight, MW=1047). 
Kawada, Kyoto University, Japan); pBI-GhPPAR- $\alpha$ plasmid and pBI-G-hPPAR- $\beta$ (a kind gift from Dr. Sarah Roberts-Thomson, Queensland University, Australia); pSG5-hPPAR- $\gamma 1$ plasmid $(\sim 1.5 \mathrm{~kb})$ (a kind gift of Dr. Willa Hsueh, University of California, Los Angeles) and pSV- $\beta$ Galactosidase Control Vector (Promega, Australia) to normalise transfection efficiencies. Cells were transfected with FuGENE 6 transfection reagent (Roche, Australia) in accordance with the manufacturer's instructions. After $24 \mathrm{~h}$, the cells were harvested and plated into 96-well plates at $5 \times 10^{4}$ cells per well in complete transfection media and allowed to attach for $2 \mathrm{~h}$. The cells were then treated with the PPAR- $\alpha$ positive control (Wy14643) [20], Gyp-XLIX or vehicle ( $0.1 \%$ DMSO). After $24 \mathrm{~h}$, the cells were lysed and assayed for luciferase and $\beta$-galactosidase activities. MK-886, a selective antagonist for PPAR- $\alpha$ [21], was added $1 \mathrm{~h}$ before addition of $\mathrm{Wy}-14643$ and the test samples. For NF- $\kappa \mathrm{B}$ luciferase activity, RAW 264.7 macrophage, THP-1 monocyte or HUVEC cell lines were transiently transfected with p-NF$\kappa \beta$-Luc (a kind gift from Dr. Sheridan Henness, University of Sydney, Australia) and pSV- $\beta$ Galactosidase Control Vector (Promega) to normalize transfection efficiencies, as described previously $[14,22,23]$. The RAW264.7 macrophages were pretreated for $1 \mathrm{~h}$ with either vehicle (DMSO) or PDTC (100 mM, a known inhibitor of NF- $\kappa \mathrm{B})$ [24], GP extract $(5-100 \mu \mathrm{g} / \mathrm{ml})$ or Gyp-XLIX (1-300 $\mu \mathrm{g} / \mathrm{ml}) 4 \mathrm{~h}$ prior to treatment with LPS $(100 \mathrm{ng} / \mathrm{ml})$. For THP-1 monocytes, the transfected cells were cultured for $46 \mathrm{~h}$ before stimulation with LPS $(10 \mu \mathrm{g} / \mathrm{ml})$ for $6 \mathrm{~h}$ after $1 \mathrm{~h}$ pretreatment with Wy-14643 $(50 \quad \mu \mathrm{M})$ and gyp-XLIX $(50 \mu \mathrm{M})$. Experiments performed in HUVEC cells (Figure 4b), the transfected cells were treated with Wy-14643 $(50 \mu \mathrm{M})$ and GypXLIX $(50 \mu \mathrm{M})$ for $24 \mathrm{~h}$ before stimulation with TNF- $\alpha(20 \mathrm{ng} / \mathrm{ml})$ for a further $6 \mathrm{~h}$. MK-886 (20 and $50 \mu \mathrm{M}$ ) was added $1 \mathrm{~h}$ before addition of compounds in both THP-1 monocyte and HUVEC cell lines experiments. Cells were lysed and assayed for luciferase and $\beta$-galactosidase activities using the Bright-Glo Luciferase Assay System and Beta-Glo Assay System (Promega, Australia), respectively. The results were expressed as relative luciferase activity (fold difference compared to negative control).

\section{Semi-quantitative $m R N A$ analysis}

Total mRNA was prepared separately from the THP-1 macrophage cells using TRIzol (Invitrogen, Australia). The relative levels of specific mRNAs were assessed by reverse transcription polymerase chain reaction (RT-PCR), as described previously [25]. Single-stranded cDNA was synthesized from $1 \mu \mathrm{g}$ of total RNA using SuperScript II Rnase H Reverse Transcriptase, as per instructions of the manufacturer (Invitrogen, Australia). PCR was performed on a thermocycler, PTC-200 DNA engine (MJ Research Inc, USA). The required cDNA was synthesized with the Platinum ${ }^{\circledR}$ Pfx DNA Polymerase method (Invitrogen, Australia). The genes examined were PPAR- $\alpha$ (S74349; 371 bp; sense: $5^{\prime}$-CTGGAAGCTTTGGCTTTACG- $3^{\prime}$ and antisense: $5^{\prime}$-GTTGTGTGACATCCCGACAG-3'), PPAR- $\beta$ (NM006238; $351 \mathrm{bp}$; sense: 5'-CTCACT GCTGGACCAACTGC- $3^{\prime}$ and antisense: $5^{\prime}$-TGT ACTGGCTCCCCTCGTTT-3'), PPAR- $\gamma$ (L40904; 382 bp; sense: 5'-GAGCCCAAGTT TGAGTTTG C-3'; 5'-TGGAAGAAGGGAAATGTTGG-3') and $\beta$-actin (NM001101; 629 bp; sense: $5^{\prime}$-GGAG TAACCAGGTCGTCCAA-3'; 5'-GAAGGTGCC CAGAATACCAA-3'). To determine the selectivity of receptors for Gyp-XLIX, the positive controls used were: Wy-14643 for PPAR- $\alpha$ [20], bezafibrate for PPAR $-\beta / \delta$ [26] and ciglitazone for PPAR $-\gamma$ [27] (Figure 8a). The PCR samples were electrophoresed on $5-12 \%$ acrylamide gel (29:1, acrylamide: $\mathrm{N}, \mathrm{N}^{\prime}$-methylene-bis-acrylamide) in TBE buffer ( $89 \mathrm{mM}$ Tris-base pH 7.6, $89 \mathrm{mM}$ boric acid, 2 mM EDTA). The gels were stained with ethidium bromide $(10 \mu \mathrm{g} / \mathrm{ml})$ and photographed on top of a $280 \mathrm{~nm}$ UV light box (Biorad ${ }^{\circledR}$ Gel Doc 1000). The gel images were digitally captured with a CCD camera and analyzed with Image J $1.29 \times(\mathrm{NIH}$, USA). RT-PCR values are presented as a ratio of the specified gene signal in the selected linear amplification cycle divided by the $\beta$-actin signal.

\section{Protein extraction and semi-quantitative immunoblotting}

Immunoblots were conducted as described previously [27, 28]. The proteins from the cells were prepared using the cell lysis buffer (Cell signaling, USA). The lysed cells were centrifuged at $16,000 \times \mathrm{g}(\mathrm{SS}-34$ rotor, Sorvall Centrifuge, USA) 
for $30 \mathrm{~min}$ and supernatants resolved by reducing SDS-PAGE (10\% polyacrylamide gels). Protein was transferred to PVDF membranes with Dunncarbonate transfer buffer $(10 \mathrm{mM}$ sodium bicarbonate, $3 \mathrm{mM}$ sodium carbonate and $15 \% \mathrm{MeOH}$, $4{ }^{\circ} \mathrm{C}$ ) and blocked in $5 \%$ skim-milk powder (Sigma, Australia) overnight. The primary antibodies (Santa Cruz Biotechnology, USA) were anti-PPAR- $\alpha$ rabbit polyclonal IgG (1:500 dilution), anti-PPAR- $\beta / \delta$ rabbit polyclonal primary antibody (1:400 dilution), anti-PPAR- $\gamma$ rabbit polyclonal primary antibody (1:500 dilution) and anti-I- $\kappa \mathrm{B} \alpha$ rabbit polyclonal (1:400 dilution) and anti-NF- $\kappa \mathrm{B}(\mathrm{p} 65)$ rabbit polyclonal (1:400 dilution). After incubation with the specified primary antibodies, the membrane was washed and further incubated with horseradish peroxidase conjugated anti-rabbit secondary antibodies (1:10,000 dilution; Promega, USA). Bound antibodies were detected using enhanced chemiluminescence with Lumi-Light Western Blotting Substrate (Roche). The membranes were exposed to X-ray film (Kodak, USA) and developed using the SRX101A X-ray developer (Konica, Taiwan). Quantitation of the results was performed by scanning the X-ray film with Molecular Analyst software (version 2.1.2, Biorad, USA) followed by densitometry with the public domain software, NIH Image, version 1.62. Protein expression was quantified by normalization to actin. The membranes were reprobed with anti-actin primary antibody (1:1000 dilution; Sigma, Australia) after stripping of the previous primary antibody by boiling the membrane in distilled water for $5 \mathrm{~min}$. The membranes were washed in fresh distilled water and re-incubated with horseradish peroxidase conjugated anti-rabbit secondary antibody and detected using the same procedure as described above. The nuclear protein $\mathrm{NF}-\kappa \mathrm{B}(\mathrm{p} 65)$ and the cellular protein $\mathrm{I}-\kappa \mathrm{B} \quad \alpha$ were extracted with CelLytic ${ }^{\mathrm{TM}}$ $\mathrm{NuCLEAR}^{\mathrm{TM}}$ Extraction Kit (Sigma, Australia) according to the manufacturer's manual. Protein contents were determined using Bradford assay method using BSA as a standard [29].

\section{Statistical analysis}

All results are expressed as means \pm SEM. Data was analysed by 1 -factor analysis of variance (ANOVA). If a statistically significant effect was found, the Newman-Keuls test was performed to isolate the difference between the groups. $p$ values less than 0.05 were considered as indicative of significance.

\section{Results}

Effects of Gyp-XLIX on LPS- and TNF- $\alpha$-induced inhibition of $I-\kappa B \alpha$ and activation of $N F-\kappa B$ in cell lines

GP has been used clinically in the treatment of various inflammatory diseases (see Introduction). $\mathrm{NF}-\kappa \mathrm{B}$ is well known to be involved in the initiation and development of various inflammatory conditions. LPS and TNF- $\alpha$ are well known pro-inflammatory agents activating the NF- $\kappa \mathrm{B}$ pathway in cell lines [30-32]. We have recently reported that gypenosides derived from GP suppress LPS-induced inducible NO synthase enzyme level by attenuating $\mathrm{NF}-\kappa \mathrm{B}$ activation in murine macrophages [12]. In the present study, we first investigated the effect of Gypenoside XLIX on LPS-induced NF- $\kappa \mathrm{B}$ activation by the same method in the same cell line. The results showed that LPS evoked NF- $\kappa \mathrm{B}$ promoter activity in RAW 264.7 macrophages (Figure 1a). Positive control PTDC (100 mM) completely inhibited this activation of $\mathrm{NF}-\kappa \mathrm{B}$ promoter activity. GP extract $(5,10,50$, and $100 \mu \mathrm{g} / \mathrm{ml})$ and $\operatorname{Gyp}-\operatorname{XLIX}(1,10$, 100 and $300 \mu \mathrm{M}$ (equivalent to $1,10,105$ and 314 $\mu \mathrm{g} / \mathrm{ml})$ also potently inhibited $\mathrm{NF}-\kappa \mathrm{B}$ promoter activity (Figure 1a).

Upon stimulation of the NF- $\kappa$ B system by LPS and $T N F-\alpha, I-\kappa B \alpha$ is phosphorylated by $I-\kappa B$ kinases and subsequently degraded to release NF$\kappa \mathrm{B}$, which is then translocated to the nucleus where it activates various genes [33]. NF- $\kappa \mathrm{B}$ activation increases the p65 subunit of $N F-\kappa B$ protein level in the nucleus, whereas the cytosolic $\mathrm{I}-\kappa \mathrm{B} \alpha$ protein level is reduced. To further evaluate the generality of the inhibitory effect of Gyp-XLIX on $\mathrm{NF}-\kappa \mathrm{B}$ activation, cytosolic and nuclear extracts from THP-1 monocyte and HUVEC cells endogenously expressing PPAR- $\alpha[34,35]$ were analyzed by immunoblotting for $\mathrm{I}-\kappa \mathrm{B} \alpha$ and NF$\kappa \mathrm{B}(\mathrm{p} 65)$ protein levels, respectively. Pretreatment of the cells with Gyp-XLIX prior to exposure to the respective stimulus was performed as described in the Methods. The results show that in the presence of LPS or TNF- $\alpha$ the protein expression of $\mathrm{I}-\kappa \mathrm{B} \alpha$ in the cytosol was decreased compared 
to that of LPS-untreated THP-1 monocyte (Figure 2a) or TNF- $\alpha$-untreated HUVEC cells (Figure 3a), respectively. In contrast, the protein expression of $\mathrm{NF}-\kappa \mathrm{B}(\mathrm{p} 65)$ in the nuclear fraction was enhanced with both stimulants (Figures $2 b$ and $3 \mathrm{~b}$, respectively). PDTC at $100 \mathrm{mM}$ normalized the reduction in cytosolic $\mathrm{I}-\kappa \mathrm{B} \alpha$ protein by LPS (Figure 2a) and to a lesser extent TNF-alpha (Figure $3 \mathrm{a}$ ) and reduced nuclear NF- $\kappa \mathrm{B}(\mathrm{p} 65)$ protein levels under these conditions (Figures $2 \mathrm{~b}$ and 3b). Similarly, Gyp-XLIX also restored I- $\kappa \mathrm{B} \alpha$ protein levels reduced by LPS and TNF- $\alpha$ in the cytosol at 100 and $300 \mu \mathrm{M}$ (Figures $2 \mathrm{a}$ and $3 \mathrm{a}$, respectively), and decreased the translocation of $\mathrm{NF}-\kappa \mathrm{B}(\mathrm{p} 65)$ to the nucleus at $300 \mu \mathrm{M}$ (Figures 2b and $3 b)$.

\section{Effects of GP extract and Gyp-XLIX on PPAR- $\alpha$ in cell lines}

PPARs (PPAR: $-\alpha,-\beta / \delta$ and $-\gamma$ ) play an important role in the transcriptional regulation of genes coding for proteins involved in lipid utilization and storage, lipoprotein metabolism, adipocyte differentiation and insulin action [36]. PPARs also control the expression of genes implicated in the inflammatory response via inhibition of different inflammatory pathways including NF- $\kappa \mathrm{B}$ [37], in which PPAR $-\alpha$ has been suggested to negatively interfere with inflammatory gene expression by up-regulation of the cytoplasmic inhibitor molecule I- $\kappa \mathrm{B}$ [38]. The inhibitory effects of GP extract and Gyp-XLIX on NF- $\kappa \mathrm{B}$ activation (see above results) and hyperlipidemia (see Introduction) suggests the possibility that their effects occur through PPARs. We tested the hypothesis by applying a selective antagonist MK-886 [21] in the THP-1 (Figure 4a) and HUVEC (Figure 4b) cell lines transfected with $\mathrm{NF}-\kappa \mathrm{B}$ luciferase reporter plasmid. Interestingly, MK-886 (20 and $50 \mu \mathrm{M})$, a selective PPAR- $\alpha$ antagonist, abolished the inhibitory effects of both Wy-14643 (50 $\mu \mathrm{M}$, an effective PPAR- $\alpha$ agonist) [20] and Gyp-XLIX $(50 \mu \mathrm{M})$ on LPS- (Figure 4a) and TNF- $\alpha$ (Figure $4 \mathrm{~b}$ ) -induced enhancement of NF- $\kappa \mathrm{B}$ luciferase activity in macrophages.

To further prove that GP-extract and Gypenoside XLIX selectively and specifically activate

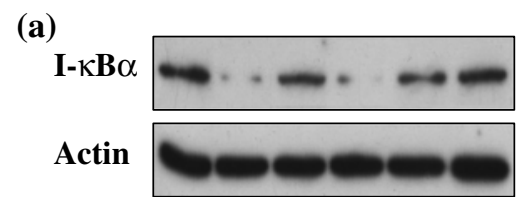

(b)
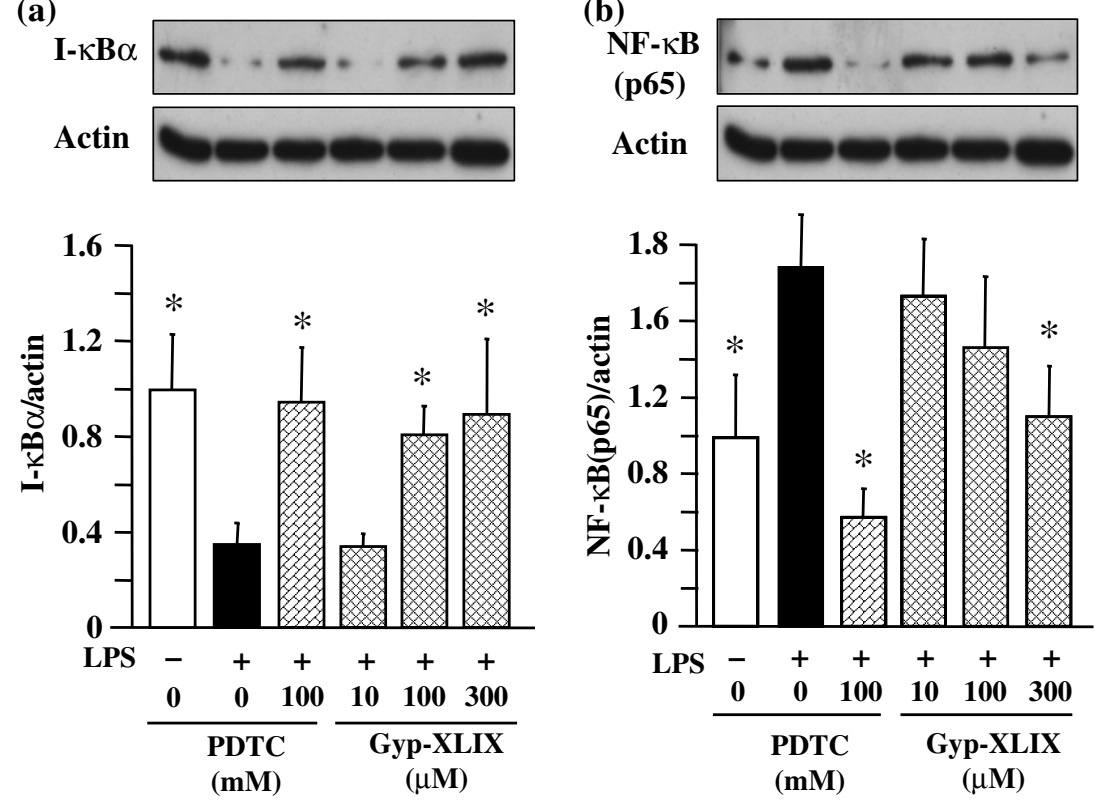

Figure 2. Effects of Gyp-XLIX on LPS-induced decrease in cytosolic I- $\kappa \mathrm{B} \alpha$ protein expression (a) and increase in translocation of $\mathrm{NF}-\kappa \mathrm{B}(\mathrm{p} 65)$ to the nucleus (b) in THP-1 monocytes. THP-1 monocytes were pretreated with Gyp-XLIX (10, 100 and $300 \mu \mathrm{M})$ and PDTC $(100 \mathrm{mM})$ for $30 \mathrm{~min}$ before stimulation with LPS $(100 \mu \mathrm{g} / \mathrm{l})$ for $5 \mathrm{~h}$. Cytoplasmic and nuclear fractions were subjected to SDS-PAGE followed by immunoblotting using anti-I- $\kappa \mathrm{B} \alpha$ and anti-NF- $\kappa \mathrm{B}(\mathrm{p} 65)$ antibodies. Protein contents were determined using the Bradford assay method with BSA as a standard. The results were normalized to actin. Levels in vehicle (LPS-) were arbitrarily assigned a value of 1.0 . All values are means \pm SEM $(n=3$ each in duplicate) vs. control (PDTC with LPS), $* p<0.05$. 
PPAR- $\alpha$, we used HEK293, a cell line lacking endogenous expression of PPAR- $\alpha$ [19] and transfected with PPAR- $\alpha$ luciferase plasmid. Like $50 \mu \mathrm{M}$ Wy-14643, which at $50 \mu \mathrm{M}$ induced PPAR- $\alpha$ luciferase activity (Figure 5a) in HEK293 cells transfected with the tK-PPREx3-Luc reporter plasmid and expression vectors for PPAR- $\alpha$, GP extract (1$100 \mu \mathrm{g} / \mathrm{ml}$ ) also concentration-dependently enhanced PPAR- $\alpha$ luciferase activity (Figure 5a). The enhancing activities of both Wy-14643 and GP extract were inhibited by MK-886 in a concentration-dependent manner (Figure 5b). Further results showed that Gyp-XLIX $(0-500 \mu \mathrm{M})$ also concentration-dependently enhanced PPAR- $\alpha$ luciferase activity $\left(\mathrm{EC}_{50}: 10.06 \mu \mathrm{M}\right)$ to a similar extent to $\mathrm{Wy}-14643$ (Figure 6a).

The selectivity of Gyp-XLIX was examined by transfecting the HEK293 cells with expression vector for PPAR $-\beta / \delta$ or PPAR- $\gamma 1$ plasmids. Whereas Gyp-XLIX effectively enhanced PPAR$\alpha$ luciferase activity, it showed minimal effects on PPAR $-\beta / \delta$ and $-\gamma 1$ luciferase activity, even at high concentrations (Figure 7a). To further confirm this selectivity for PPAR- $\alpha$, THP-1 derived mac- rophage, a cell line endogenously expressing the three PPAR isoforms [18, 39], was employed mRNAs and protein were extracted from the cells and examined by RT-PCR and immunoblotting, respectively. Treatment for 48 hours with vehicle (DMSO), Gyp-XLIX and the respective positive controls for PPAR $-\alpha(\mathrm{Wy}-14643,50 \mu \mathrm{M})$, PPAR$\beta / \delta$ (bezafibrate, $100 \mu \mathrm{M}$ ) and PPAR- $\gamma$ (ciglitazone, $10 \mu \mathrm{M}$ ), showed comparable profiles in both PPAR- $\alpha$ mRNA (Figure 7b) and protein (Figure 7c) expression, with minimal or no significant increase in mRNA and protein expression for PPAR $-\beta / \delta$ and $-\gamma$.

Finally the specificity of Gyp-XLIX for PPAR- $\alpha$ was examined using the inhibitor MK-886. HEK 293 cells were transiently transfected with the reporter construct and expression vector for PPAR$\alpha$ as described above. MK-886 (20 $\mu \mathrm{M}$ and $50 \mu \mathrm{M})$ was added $1 \mathrm{~h}$ prior to addition of $\mathrm{Wy}-14643$ (50 $\mu \mathrm{M})$ and Gyp-XLIX $(50 \mu \mathrm{M})$. The induction of PPAR- $\alpha$ luciferase activity by $\mathrm{Wy}-14643$ was completely suppressed by MK-886 at $50 \mu \mathrm{M}$ (Figure 8), consistent with previous findings [21]. Similarly, Gyp-XLIX-induced enhancement of (a)
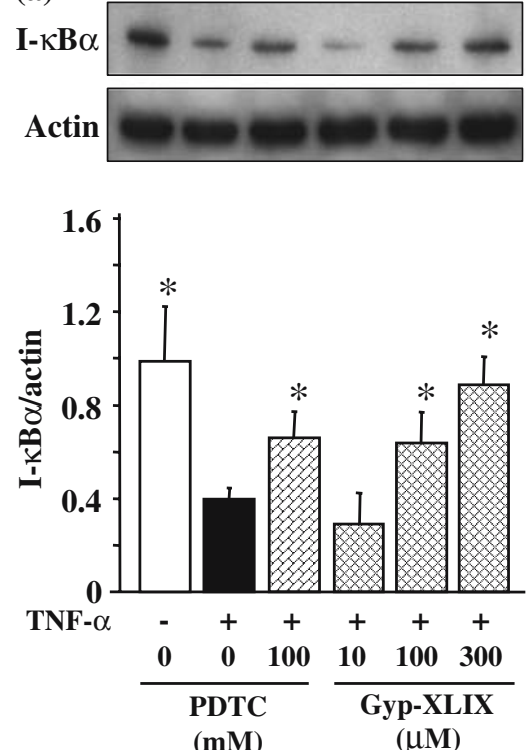

(b)
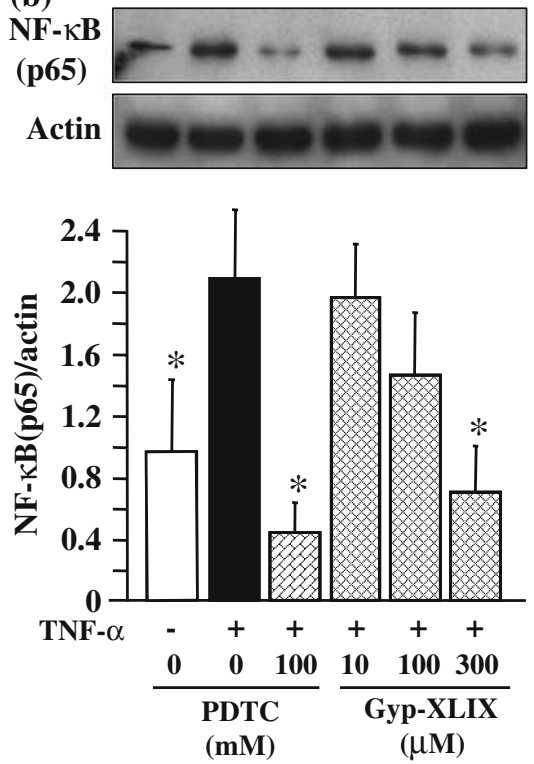

Figure 3. Effects of Gyp-XLIX on tumor necrosis factor (TNF)- $\alpha$-induced decrease in cytosolic I- $\kappa \mathrm{B} \alpha$ protein expression (a) and increase in translocation of NF- $\kappa \mathrm{B}(\mathrm{p} 65)$ to the nucleus (b) in human umbilical vein endothelial cells (HUVEC) cells. HUVEC cells were pretreated with Gyp-XLIX $(10,100$ and $300 \mu \mathrm{M})$ and PDTC $(100 \mathrm{mM})$ for 30 min before stimulated with TNF- $\alpha(20 \mathrm{ng} / \mathrm{ml})$ for $5 \mathrm{~h}$. Cytoplasmic and nuclear fractions were subjected to SDS-PAGE followed by immunoblotting using anti-I- $\kappa \mathrm{B} \alpha$ and anti$\mathrm{NF}-\kappa \mathrm{B}(\mathrm{p} 65)$ antibodies. Protein contents were determined using the Bradford assay method with BSA as a standard. The results were normalized to actin. Levels in vehicle (LPS-) were arbitrarily assigned a value of 1.0. All values are means \pm SEM $(n=3$ each in duplicate) vs. control (PDTC with LPS), ${ }^{*} p<0.05$. 
PPAR- $\alpha$ promoter activity was attenuated by MK886 concentration-dependently (Figure 8). This result was further confirmed in studies using the THP-1 derived-macrophage, which showed a decrease in PPAR- $\alpha$ mRNA (Figure 9a) and protein (Figure 9b) expression following treatment with Gyp-XLIX in the presence of MK-886. This confirms the specificity of Gyp-XLIX for PPAR- $\alpha$.

Taken together the results consolidate the finding that Gyp-XLIX is an activator for PPAR- $\alpha$ with similar potency to Wy-14643, an activity also found in the GP extract from which it is derived, and that the activation is selective for PPAR- $\alpha$.

\section{Discussion}

Compounds derived from plant extracts are being increasingly utilized to treat a wide variety of clinical diseases. Identifying lead compounds from nature with increasing efficacy and safety may be particularly important for potential treatment of the growing population of predyslipidaemic patients as well as patients suffering from ischemic heart disease and hypertension. GP is a traditional Chinese medicine popular in a number of countries as a treatment for hyperlipidemia and various inflammatory diseases, especially in respiratory and cardiovascular systems (see Introduction). The medicinal properties of GP have been mainly attributed to the dammarane type triterpene components, also known as dammarane saponins which make up about $2.4 \%$ of the dried herb, with $\sim 75 \%$ being gypenosides [40]. As gypenosides are structurally related to ginseng saponins, the ginsenosides, which are the well-known biologically active principles in Korean ginseng, GP has received much attention in recent times. Gypenosides have been reported to be effective in the treatment of cardiovascular diseases, especially in hyperlipidemia and ischemic heart diseases [10, 41] and atherosclerosis [13]. We have recently demonstrated that GP extract improves hyperlipidemia and hyperglycemia in Zucker diabetic fatty rat, a genetic model of type 2 diabetes and obesity (our unpub-
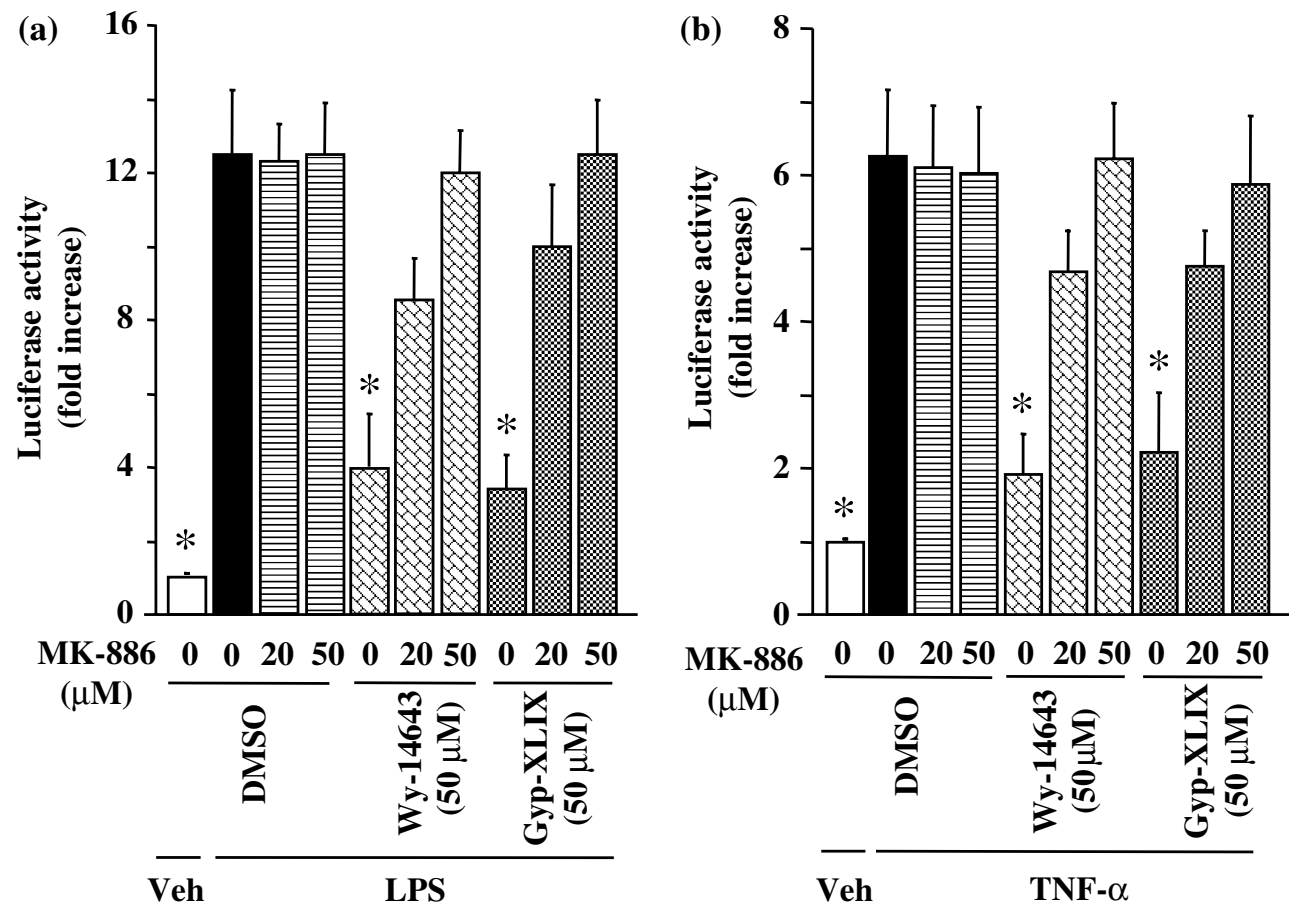

Figure 4. Effects of Gyp-XLIX on LPS (100 $\mu \mathrm{g} / \mathrm{ml})$ (a)- and TNF- $\alpha(20 \mathrm{ng} / \mathrm{ml})$ (b)-induced NF- $\kappa \mathrm{B}$ activation in the presence of MK-886 (a specific PPAR- $\alpha$ antagonist) in THP-1 monocyte (a) and HUVEC (b) cell lines transfected with NF- $\kappa$ B luciferase reporter gene. The results were expressed as relative luciferase activity (fold difference compared to negative control). Wy-14643 (a selective PPAR- $\alpha$ activator) was used as a positive control. Levels in vehicle (DMSO without LPS or TNF- $\alpha$ ) were arbitrarily assigned a value of 1.0. All values are means \pm SEM ( $n=3$ each in duplicate) vs. control (DMSO, MK-886 $0 \mu$ M with LPS or TNF$\alpha),{ }^{*} p<0.05$. Veh: vehicle. 

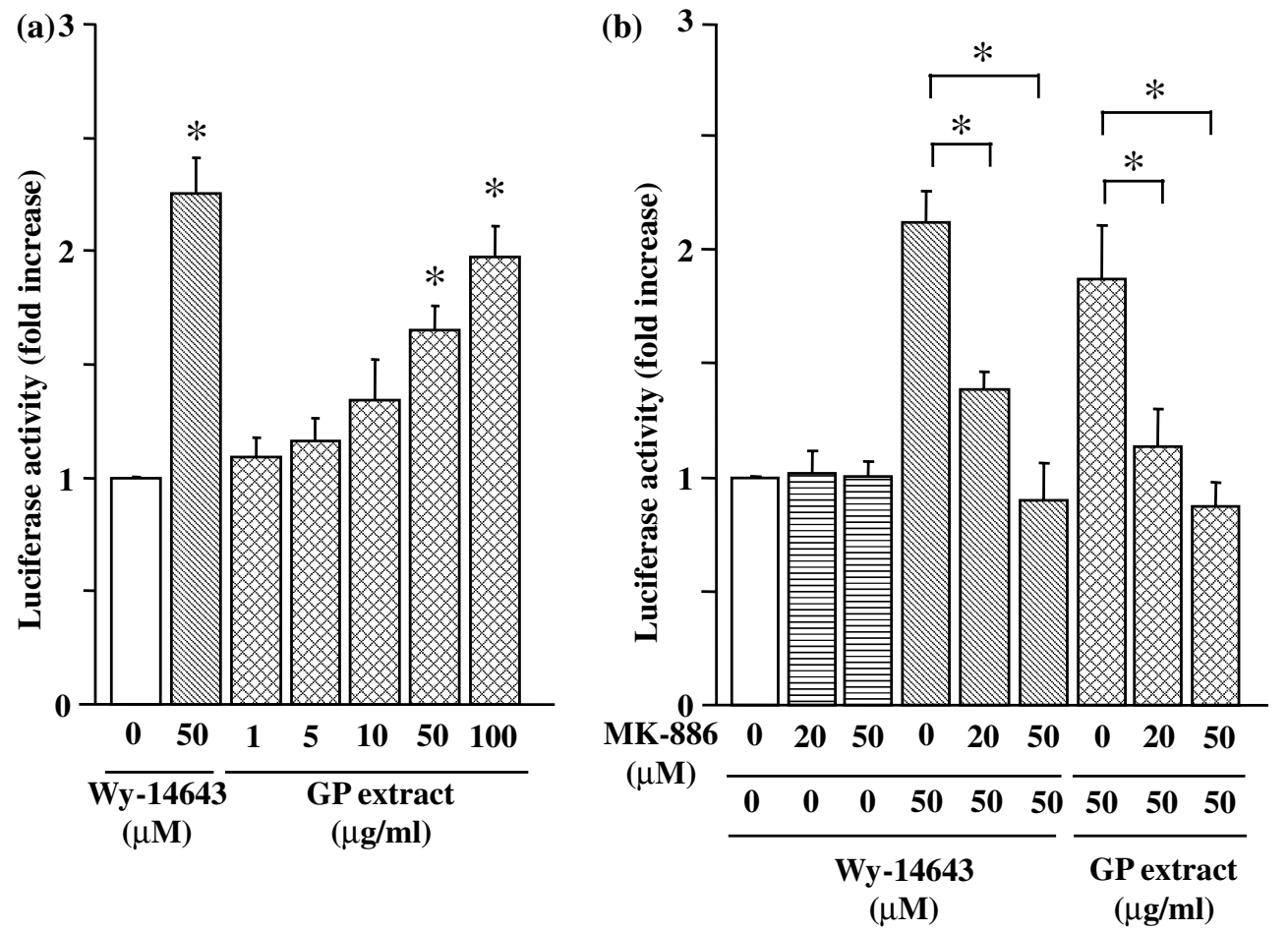

Figure 5. Effects of GP extract on PPAR- $\alpha$ activity in the absence $(0-100 \mu \mathrm{g} / \mathrm{ml})$ (a) or presence (b) of MK-886 $(20$ and $50 \mu \mathrm{M})$, a selective PPAR- $\alpha$ antagonist in human embryonic kidney (HEK 293) cell line. Wy-14643 (a selective PPAR- $\alpha$ activator) was used as a positive control. Levels in control (con, Wy-14643 $0 \mu \mathrm{M}$ and/or MK-886 $0 \mu \mu \mathrm{M}$ ) were arbitrarily assigned a value of 1.0. All values are means $\pm \operatorname{SEM}\left(n=3\right.$, each in duplicate) vs. control, ${ }^{*} p<0.05$.

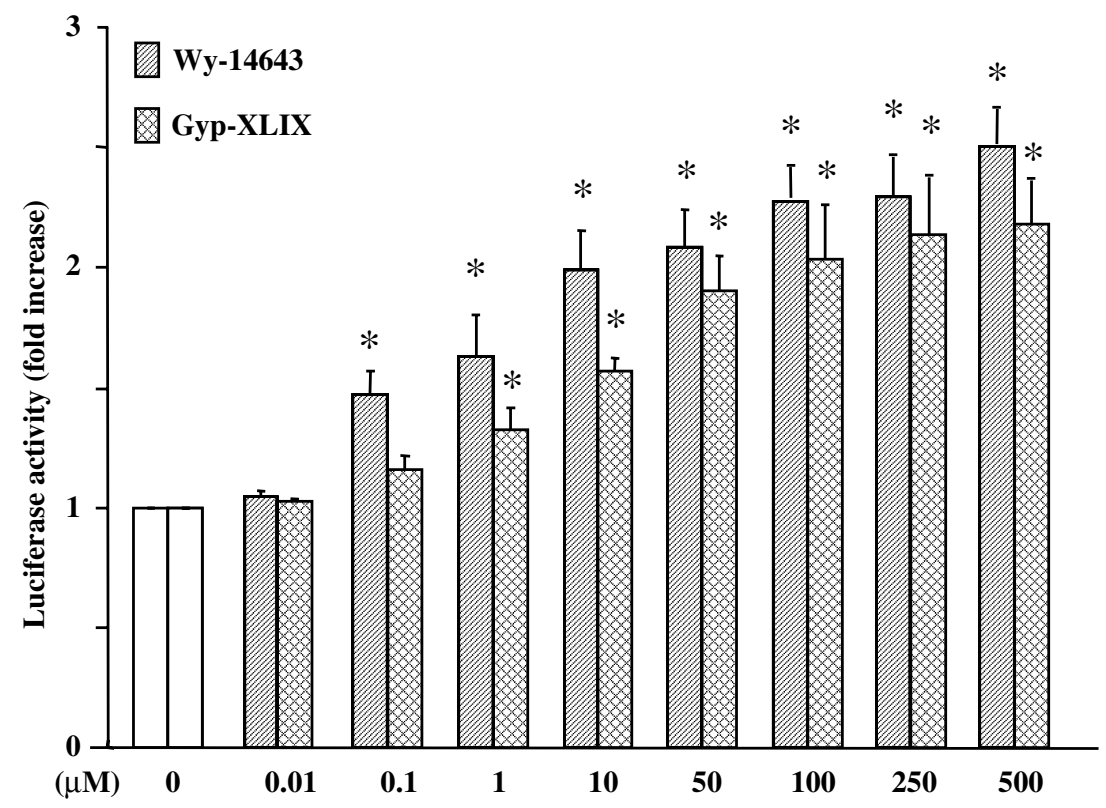

Figure 6. Effects of Gyp-XLIX $(0-500 \mu \mathrm{M})$ on PPAR- $\alpha$ activity in human embryonic kidney (HEK 293) cell line. Wy-14643 (a selective PPAR- $\alpha$ activator) was used as a positive control. Levels in control (Wy-14643 or Gyp-XLIX $0 \mu \mathrm{M}$ ) were arbitrarily assigned a value of 1.0. All values are means $\pm \operatorname{SEM}\left(n=3\right.$, each in duplicate) vs. control, ${ }^{*} p<0.05$. 
lished data). Gyp-XLIX (C52H86O21: 1047.2388, Figure $1 \mathrm{~b}$ ) is one of the main gypenoside components contained in GP. Although Gyp-XLIX has been known for more than 20 years [42], its biological activities have not been addressed. In the current study we have isolated Gyp-XLIX from an extract of GP used therapeutically in China and investigated the receptor-based mechanism of its potential anti-inflammatory and lipidlowering actions. NF- $\kappa \mathrm{B}$ is one of the main transcription factors thought to be involved in inflammation and allergic disorders. Most of the inflammatory genes overexpressed in inflammation, such as those encoding proinflammatory cytokines, chemokines, adhesion molecules and inflammatory enzymes, contain $\kappa \mathrm{B}$ sites for binding of $\mathrm{NF}-\kappa \mathrm{B}$ within their promoter, suggesting that these genes are controlled prominantly by $\mathrm{NF}-\kappa \mathrm{B}$ [5]. NF- $\kappa \mathrm{B}$ is a heterodimer of two subunits, $\mathrm{p} 50$ $(\mathrm{NF}-\kappa \mathrm{B} 1)$ and $\mathrm{p} 65(\mathrm{Rel} \mathrm{A})$, the latter which is normally present in the cytoplasm in an inactive state complexed with its inhibitory subunit, I- $\kappa \mathrm{B} \alpha$. Upon phosphorylation and subsequent degradation of I $\kappa \mathrm{B} \alpha$, the nuclear localization signal on the p50-p65 heterodimer is exposed, leading to nuclear translocation and transcription of dependent genes [43]. In the present study, GP extract and one of its main components Gyp-XLIX were shown to inhibit LPS-induced NF- $\kappa$ B activation in murine macrophages. Furthermore, Western blots demonstrated that Gyp-XLIX restored the LPS- and TNF- $\alpha$-induced decrease in cytosolic I$\kappa \mathrm{B} \alpha$ protein expression and inhibited the appearance of $\mathrm{NF}-\kappa \mathrm{B}(\mathrm{p} 65)$ in the nucleus in THP-1 monocyte and HUVEC cells. These results therefore suggest that inhibition of NF- $\kappa \mathrm{B}$ activation is an important mechanism of GP action in the treatment of various inflammatory diseases, in which Gyp-XLIX is, at least in part, responsible.

We have established for the first time in the present study that the effects of GP and its isolated gypenoside component are mediated through a
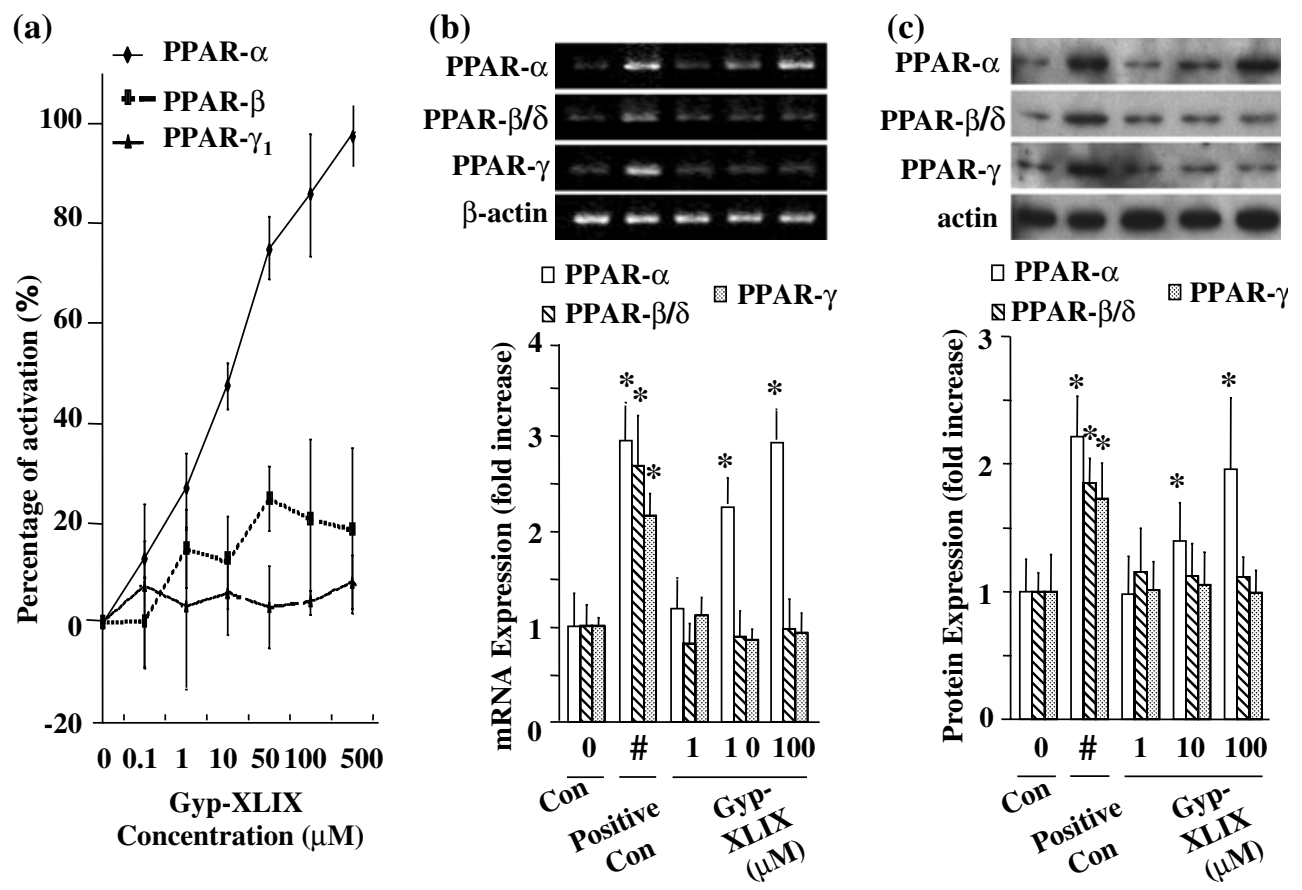

Figure 7. Effects of Gyp-XLIX on PPAR- $\alpha$ activity. (a) The percentage of activation of luciferase activity (\%) in HEK293 cell line transiently transfected with tK-PPREx3-Luc plasmid as a reporter plasmid, pBI-G-hPPAR- $\alpha$ or pBI-G-hPPAR- $\beta / \delta$ or pSG5hPPAR- $\gamma 1$ plasmid as expression vectors and pSV- $\beta$-Galactosidase as a reference plasmid; (b) mRNA and (c) protein expression of

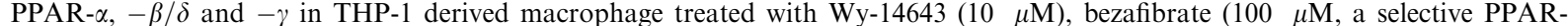
$\beta / \delta$ activator), ciglitazone (10 $\mu \mathrm{M}$, a selective PPAR- $\gamma$ activator) and Gyp-XLIX (10, 100 and $300 \mu \mathrm{M})$. Total mRNAs and protein were prepared from the cell pellets using TRIzol and cell lysis, and analyzed with RT-PCR and immunoblotting methods, respectively. The results were normalised to $\beta$-actin (for mRNA) or actin (for protein). Control (con) levels were arbitrarily assigned a value of 1.0. All values are means $\pm \operatorname{SEM}\left(n=3\right.$ each in duplicate) vs. control, ${ }^{*} p<0.05$. 
PPAR- $\alpha$-mediated process. PPAR- $\alpha$ is expressed not only in metabolically active tissues including the liver, heart, kidney, skeletal muscle and brown fat, but also in monocyte/macrophages, vascular smooth muscle cells, and endothelial cells [44]. Further, PPAR- $\alpha$ agonists have been in use for over 4 years in the treatment of dyslipidemia, mainly for their actions of lowering TG levels [44]. Besides, PPAR- $\alpha$ activators have been also shown to negatively regulate NF- $\kappa \mathrm{B}$ driven gene transcription in differnt cellular models $[32,45,46]$. In a recent study activation of PPAR- $\alpha$ by fibrates has been shown to terminate activation of inflammatory pathways through modulation of NF- $\kappa \mathrm{B}$ translocation to the nucleus and also downregulation of basal NF- $\kappa \mathrm{B}$ expression, terminating activation of inflammatory pathways [47]. PPAR- $\alpha$ activators increase $\mathrm{I}-\kappa \mathrm{B} \alpha$ mRNA and protein levels in human aortic smooth muscle cells [48]. This action of PPAR- $\alpha$ activation on $\mathrm{I}-\kappa \mathrm{B} \alpha$ expression likely contributes to the overall antiinflammtory activities of PPAR- $\alpha$ agonists. Since GP is known to elicit anti-inflammatory, lipidlowering and NF- $\kappa \mathrm{B}$ activation-inhibiting properties, and since all these events may occur through activation of PPAR- $\alpha$, we hypothesized that GP may have a PPAR- $\alpha$ activator activity. First we tested this hypothesis by examining the effect of MK-886, an antagonist specific for PPAR- $\alpha$ [21] on GP and Gyp-XLIX activities. The effects of Gyp-XLIX $(50 \mu \mathrm{M})$ on LPS- and TNF- $\alpha$-induced enhancement of NF- $\kappa \mathrm{B}$ activity in macrophages were completely abolished in the presence of MK$886(50 \mu \mathrm{M})$, consistent with the parallel inhibition of the selective PPAR- $\alpha$ agonist Wy-14643 (50 $\mu \mathrm{M}$, a potent selective PPAR- $\alpha$ agonist) [20] under the same conditions. The results suggest that Gyp-XLIX most probably inhibits LPS- and TNF- $\alpha$-induced NF- $\kappa$ B activation by activating PPAR- $\alpha$. Further results demonstrated that GP extract and Gyp-XLIX $\left(\mathrm{EC}_{50}: 10.1 \mu \mathrm{M}\right)$ concentration-dependently enhanced PPAR- $\alpha$ luciferase activity in HEK 293 cells transfected with the tKPPREx3-Luc reporter plasmid and expression vectors for PPAR- $\alpha$. Additionally, Gyp-XLIX also enhanced PPAR- $\alpha$ mRNA and protein expression in HEK293 cells transiently transfected with the reporter construct and expression vector for PPAR- $\alpha$. Furthermore, these enhancing activities were inhibited by MK-886, suggesting specific

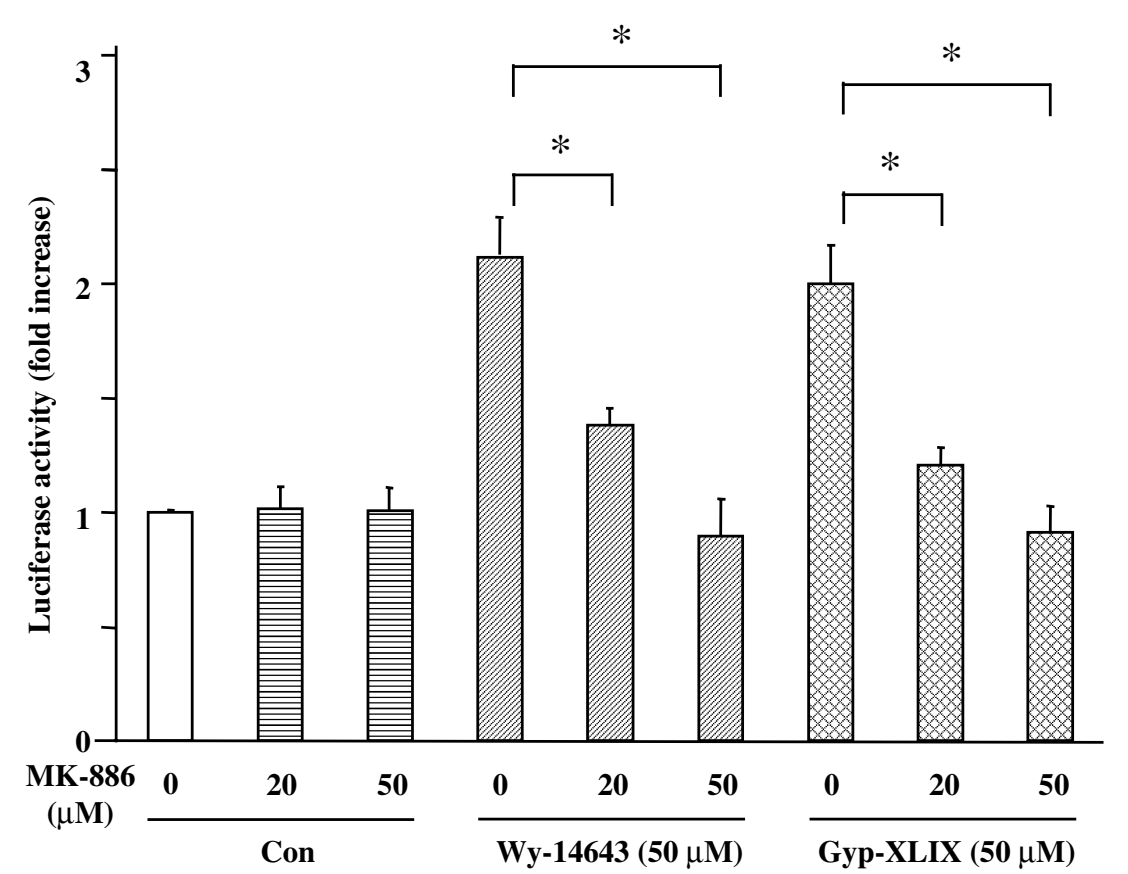

Figure 8. Effects of Gyp-XLIX on PPAR- $\alpha$ activity in the presence of MK-886 (a selective PPAR- $\alpha$ antagonist) in human embryonic kidney (HEK 293) cell line. Wy-14643 (a selective PPAR- $\alpha$ activator) was used as a positive control. Levels in control (con, MK-886 $0 \quad \mu \mathrm{M})$ were arbitrarily assigned a value of 1.0. All values are means $\pm \operatorname{SEM}(n=3$, each in duplicate) vs. control, $* p<0.05$. 

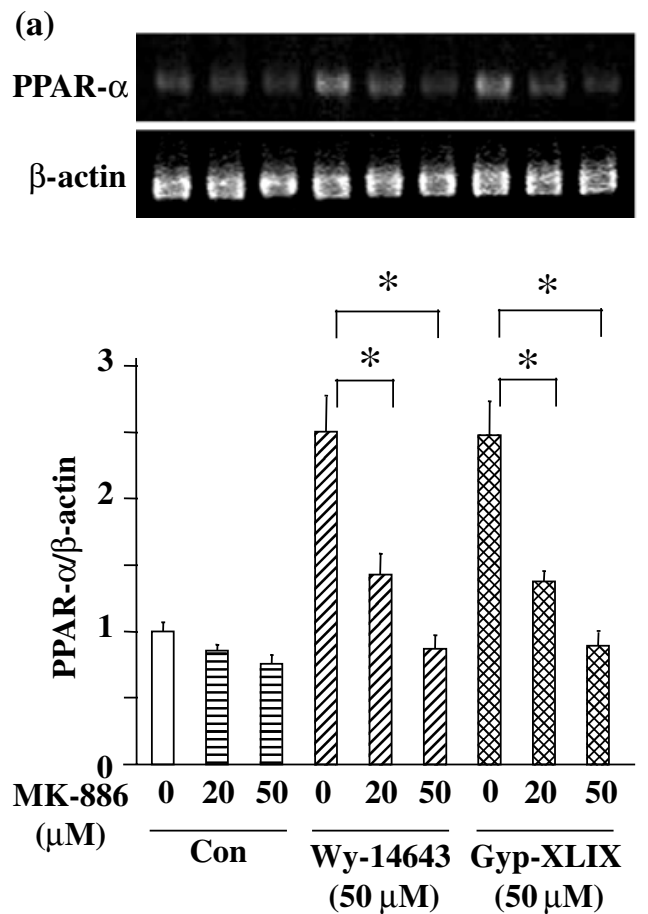

(b)
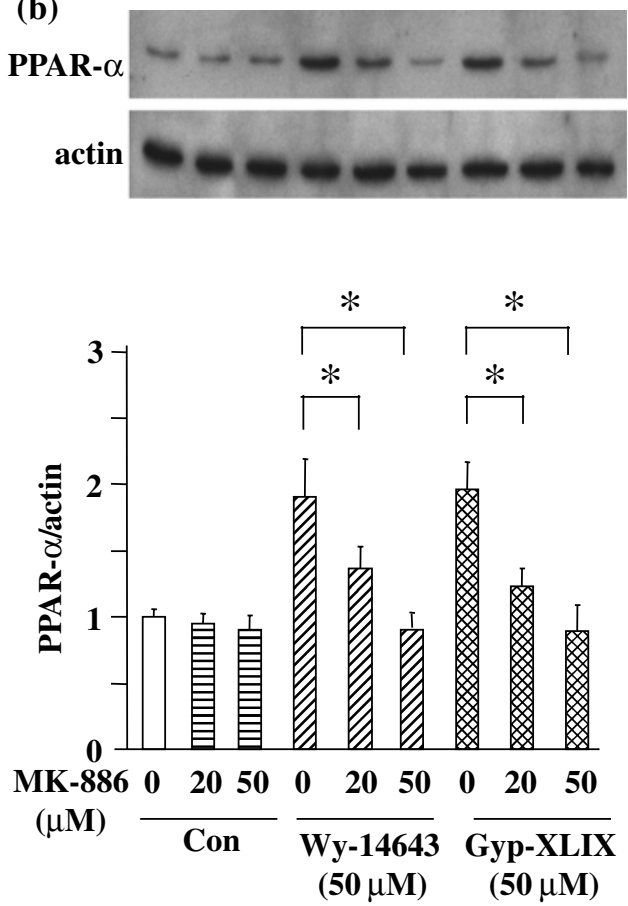

Figure 9. Effects of Gyp-XLIX (50 $\mu \mathrm{M})$ on PPAR- $\alpha$ mRNA (a) and protein (b) expression in the presence of MK886 (20 and 50 $\mu \mathrm{M})$ in THP-1 derived macrophage. The macrophages were treated respectively with vehicle or compounds for a further $48 \mathrm{~h}, 1 \mathrm{~h}$ after MK-886 was added. Total mRNAs and proteins were prepared from the cell pellets using TRIzol and cell lysis, and analyzed with RT-PCR and immunoblotting methods, respectively. The results were normalised to $\beta$-actin (for mRNA) or actin (for protein). Control (con, MK-886 $0 \mu \mathrm{M}$ ) levels were arbitrarily assigned a value of 1.0. All values are means \pm SEM $(n=3$ each in duplicate) vs. control, ${ }^{*} p<0.05$.

activation by Gyp-XLIX of PPAR- $\alpha$. The fact that Gyp-XLIX potently enhanced PPAR- $\alpha$ (luciferase activity, mRNA and protein expression), without affecting PPAR- $\beta / \delta$ or PPAR- $\gamma 1$, in the HEK 293 cells transfected with expression vectors and in THP-1-derived macrophage endogenously expressing the three PPAR isoforms, demonstrated its selectivity for PPAR- $\alpha$.

In conclusion, our findings that suggest that Gyp-XLIX isolated from the natural product Chinese medicine Gynostemma pentaphyllum inhibits inflammatory stimuli-induced NF- $\kappa \mathrm{B}$, providing a rationale for the use of this extract in various inflammatory and cardiovascular conditions. The work has demonstrated for the first time that the GP extract effects occur at least in part through activation of PPAR- $\alpha$, an effect also present in the major component gypenoside GypXLIX isolated from the extract. These studies provide potentially important insight into molecular mechanisms of action of GP on inflammation and hyperlipidemia.

\section{Acknowledgements}

The authors wish to thank Ankang Pharmaceutical Company Beijing, China, for its generous gift of gypenosides extract, and Dr Rujee K. Duke and $\mathrm{Mr}$ Bruce N. Tattam for their assistance in the project.

\section{References}

1. Siebenlist U., Franzoso G. and Brown K., Structure, regulation and function of $\mathrm{NF}-\kappa \mathrm{B}$. Ann. Rev. Cell. Biol. 10: 405-455, 1994.

2. Blackwell T.S. and Christman J.W., The role of nuclear factor kappa B in cytokine gene regulation. Am. J. Respir. Cell. Mol. Biol. 17: 3-9, 1997.

3. Blackwell T.S., Lancaster L.H. and Christman J.W., Nuclear factor kappa B: a pivotal role in the systemic response syndrome and new target for therapy. Intensive Care Med. 24: 1131-1138, 1998.

4. Pande V. and Ramos M.J., NF-kappaB in human disease: current inhibitors and prospects for de novo structure based design of inhibitors. Curr. Med. Chem. 12: 357-374, 2005. 
5. Christman J.W., Sadikot R.T. and Blackwell T.S., The role of nuclear factor-kappa B in pulmonary diseases. Chest 117: 1482-1487, 2000

6. Collins T., Endothelial nuclear factor-kappa B and the initiation of the atherosclerotic lesion. Lab. Invest. 68: 499508, 1993.

7. Blumert M. and Liu J.L., Jiaogulan in China's "Immortality Herb". Torchlight Publishing Inc., Badger, USA, 1999.

8. Li L., Jiao L. and Lau B.H., Protective effects of gypenosides against oxidative stress in phagocytes, vascular endothelial cells and liver microsomes. Cancer Biother. 8: 263-272, 1993.

9. Chen W.C., Hau D.M., Chen K.T., Wang M.I. and Lin I.H., Protective effects of Gynostemma pentaphyllum in gamma-irradiated mice. Am. J. Chin. Med. 24: 83-92, 1996.

10. Tanner M.A., Bu X., Steimle J.A. and Myers P.R., The direct release of nitric oxide by gypenosides derived from the herb Gynostemma pentaphyllum. Nitric Oxide 3: 359365, 1999.

11. Zhou Z., Wang Y., Zhou Y. and Zhang S., Effect of gynostemma pentaphyllum mak on carcinomatous conversions of golden hamster cheek pouches induced by dimethylbenzanthracene: a histological study. Chin. Med. J. (Engl) 111: 847-850, 1998.

12. Aktan F., Henness S., Roufogalis B.D. and Ammit A.J., Gypenosides derived from Gynostemma pentaphyllum suppress NO synthesis in murine macrophages by inhibiting iNOS enzymatic activity and attenuating NF-kappaBmediated iNOS protein expression. Nitric Oxide 8: 235242, 2003.

13. Li L. and Lau B., Protection of vascular endothelial cells from hydrogen peroxide induced oxidant injury by gypenosides, saponins of Gynostemma pentaphyllum. Phytother. Res. 7: 299-304, 1993.

14. Guo W.Y. and Wang W.X., Cultivation and utilisation of Gynostemma pentaphyllum. Publishing House of Electronics, Science and Technology University, pp 1-261, 1993.

15. Wang J., Lu Z., Chi J., Wang W., Su M., Kou W., Yu P., Yu J., Chen L., Zhu J.S. and Chang J., Multicenter clinical trial of the serum lipid-lowering effects of a Monascus purpureus (red yeast) rice preparation from traditional Chinese medicine. Curr. Ther. Res. 58: 964-978, 1997.

16. Coll J.C. and Bowden B.F., The application of vacuum liquid chromatography to the separation of terpene mixtures. J. Nat. Prod. 49: 934-936, 1986.

17. Takemoto T., Arihara S., Nakajima T. and Okuhira M., Studies on the constituents of fructus Momordicae. II. Structure of sapogenin. Yakugaku Zasshi 103: 1155-1166, 1983.

18. Rival Y., Beneteau N., Chapuis V., Taillandier T., Lestienne F., Dupont-Passelaigue E., Patoiseau J.F., Colpaert F.C. and Junquero D., Cardiovascular drugs inhibit MMP9 activity from human THP-1 macrophages. DNA. Cell Biol. 23: 283-292, 2004

19. Bramlett K.S., Houck K.A., Borchert K.M., Dowless M.S., Kulanthaivel P., Zhang Y., Beyer T.P., Schmidt R., Thomas J.S., Michael L.F., Barr R., Montrose C., Eacho P.I., Cao G. and Burris T.P., A natural product ligand of the oxysterol receptor, liver X receptor. J. Pharmacol. Exp. Ther. 307: 291-296, 2003.

20. Frederiksen K.S., Wulff E.M., Sauerberg P., Mogensen J.P., Jeppesen L. and Fleckner J., Prediction of PPARalpha ligand-mediated physiological changes using gene expression profiles. J. Lipid Res. 45: 592-601, 2004.
21. Kehrer J.P., Biswal S.S., La E., Thuillier P., Datta K., Fischer S.M. and Vanden Heuvel J.P., Inhibition of peroxisome-proliferator-activated receptor (PPAR) alpha by MK886. Biochem. J. 356: 899-906, 2001.

22. Sen C.K. and Bagchi D., Regulation of inducible adhesion molecule expression in human endothelial cells by grape seed proanthocyanidin extract. Mol. Cell Biochem. 216: 17, 2001.

23. Kikuchi T., Hagiwara K., Honda Y., Gomi K., Kobayashi T., Takahashi H., Tokue Y., Watanabe A. and Nukiwa T., Clarithromycin suppresses lipopolysaccharide-induced interleukin-8 production by human monocytes through AP-1 and NF-kappa B transcription factors. J. Antimicrob. Chemother. 49: 745-755, 2002.

24. Kim S.H., Kang Y.J., Kim W.J., Woo D.K., Lee Y., Kim D.I., Park Y.B., Kwon B.S., Park J.E. and Lee W.H., TWEAK can induce pro-inflammatory cytokines and matrix metalloproteinase-9 in macrophages. Circ. J. 68: 396-399, 2004.

25. Abe A., Kiriyama Y., Hirano M., Miura T., Kamiya H., Harashima H. and Tokumitsu Y., Troglitazone suppresses cell growth of KU812 cells independently of PPARgamma. Eur. J. Pharmacol. 436: 7-13, 2002.

26. Krey G., Braissant O., L'Horset F., Kalkhoven E., Perroud M., Parker M.G. and Wahli W., Fatty acids, eicosanoids, and hypolipidemic agents identified as ligands of peroxisome proliferator-activated receptors by coactivator-dependent receptor ligand assay. Mol. Endocrinol. 11: 779-791, 1997.

27. Davies G.F., McFie P.J., Khandelwal R.L. and Roesler W.J., Unique ability of troglitazone to up-regulate peroxisome proliferator-activated receptor-gamma expression in hepatocytes. J. Pharmacol. Exp. Ther. 300: 72-77, 2002.

28. Nho C.W. and O'Dwyer P.J., NF-kappaB activation by the chemopreventive dithiolethione oltipraz is exerted through stimulation of MEKK3 signaling. J. Biol. Chem. 279: 26019-26027, 2004.

29. Bradford M.M., A rapid and sensitive method for the quantitation of microgram quantities of protein utilizing the principle of dye-binding. Anal. Biochem. 72: 248-254, 1976.

30. Orthner C.L., Rodgers G.M. and Fitzgerald L.A., Pyrrolidine dithiocarbamate abrogates tissue factor (TF) expression by endothelial cells: evidence implicating nuclear factor-kappa B in TF induction by diverse agonists. Blood 86: 436-443, 1995.

31. Marx N., Mackman N., Schonbeck U., Yilmaz N., Hombach V., Libby P. and Plutzky J., PPARalpha activators inhibit tissue factor expression and activity in human monocytes. Circulation 103: 213-219, 2001.

32. Neve B.P., Corseaux D., Chinetti G., Zawadzki C., Fruchart J.C., Duriez P., Staels B. and Jude B., PPAR $\alpha$ agonists inhibit tissue factor expression in human monocytes and macrophages. Circulation 103: 207-212, 2001.

33. Monaco C. and Paleolog E., Nuclear factor kappaB: a potential therapeutic target in atherosclerosis and thrombosis. Cardiovasc. Res. 61: 671-682, 2004

34. Chinetti G., Zawadski C., Fruchart J.C. and Staels B., Expression of adiponectin receptors in human macrophages and regulation by agonists of the nuclear receptors PPARalpha, PPARgamma, and LXR. Biochem. Biophys. Res. Commun. 314: 151-158, 2004.

35. Inoue I., Shino K., Noji S., Awata T. and Katayama S., Expression of peroxisome proliferator-activated receptor alpha (PPAR alpha) in primary cultures of human vascular 
endothelial cells. Biochem. Biophys. Res. Commun. 246: 370-374, 1998.

36. Torra I.P., Chinetti G., Duval C., Fruchart J.C. and Staels B., Peroxisome proliferator-activated receptors: from transcriptional control to clinical practice. Curr. Opin. Lipidol. 12: 245-254, 2001.

37. Blanquart C., Barbier O., Fruchart J.C., Staels B. and Glineur C., Peroxisome proliferator-activated receptors: regulation of transcriptional activities and roles in inflammation. J. Steroid. Biochem. Mol. Biol. 85: 267-273, 2003.

38. Vanden Berghe W., Vermeulen L., Delerive P., De Bosscher K., Staels B. and Haegeman G.A., A paradigm for gene regulation: inflammation, NF-kappaB and PPAR. Adv. Exp. Med. Biol. 544: 181-196, 2003.

39. Perez A., Thuillard J.L., Bentzen C.L. and Niesor E.J., Expression of nuclear receptors and apo E secretion during the differentiation of monocytic THP-1 cells into macrophages. Cell. Biol. Toxicol. 19: 95-105, 2003.

40. Kuwahara M., Kawanishi F., Komiya T. and Oshio H., Dammarane saponins of Gynostemma pentaphyllum Makino and isolation of malonylginsenosides-Rb1, -Rd, and malonylgypenoside V. Chem. Pharm. Bull. 37: 135-139, 1989.

41. la Cour B., Molgaard P. and Yi Z., Traditional Chinese medicine in treatment of hyperlipidaemia. J. Ethnopharmacol. 46: 125-129, 1995.

42. Takemoto T., Arihara S., Yoshikawa K., Hino K., Nakajima T. and Okuhira M., Studies on the constituents of cucurbitaceae plants. XII. On the saponin constituents of Gynostemma pentaphyllum Makino (8). Yakugaku Zasshi 104: 1155-1162, 1984.
43. Sun N.J., Woo S.H., Cassady J.M. and Snapka R.M., DNA polymerase and topoisomerase II inhibitors from Psoralea corylifolia. J. Natl. Prod. 61: 362-366, 1998.

44. Francis G.A., Annicotte J.S. and Auwerx J., PPAR-alpha effects on the heart and other vascular tissues. Am. J. Physiol. Heart Circ. Physiol. 285: H1-H9, 2003.

45. Delerive P., De Bosscher K., Besnard S., Vanden Berghe W., Peters J.M., Gonzalez F.J., Fruchart J.C., Tedgui A., Haegeman G. and Staels B., Peroxisome proliferatoractivated receptor alpha negatively regulates the vascular inflammatory gene response by negative cross-talk with transcription factors NF-kappaB and AP-1. J. Biol. Chem. 274: 32048-32054, 1999.

46. Marx N., Sukhova G.K., Collins T., Libby P. and Plutzky J., PPARalpha activators inhibit cytokine-induced vascular cell adhesion molecule- 1 expression in human endothelial cells. Circulation 99: 3125-3131, 1999.

47. Kleemann R., Gervois P.P., Verschuren L., Staels B., Princen H.M. and Kooistra T., Fibrates down-regulate IL1-stimulated C-reactive protein gene expression in hepatocytes by reducing nuclear p50-NFkappa B-C/EBP-beta complex formation. Blood 101: 545-551, 2003.

48. Delerive P., Gervois P., Fruchart J.C. and Staels B., Induction of IkappaBalpha expression as a mechanism contributing to the anti-inflammatory activities of peroxisome proliferator-activated receptor-alpha activators. J. Biol. Chem. 275: 36703-36707, 2000. 